RETORIKA: Jurnal Ilmu Bahasa, Vol. 4, No. 1 April 2018, Page 43-52

Available Online at https://ejournal.warmadewa.ac.id/index.php/jret

P-ISSN: 2406-9019

E-ISSN: 2443-0668

\title{
SEEING RECOUNT FROM SYSTEMIC FUNCTIONAL LINGUISTIC PERSPECTIVE: SINE QUA NON ATTRIBUTES
}

\author{
Rialita Kusuma Shinta Dewi \& Eri Kurniawan \\ Universitas Pendidikan Indonesia \\ rialitakusumashintadewi@gmail.com
}

Received: 05-02-2018

Revised: 04-03-2018

Accepted: 20-03-2018

\begin{abstract}
It is known that traditional grammar is nowadays unlikely to be featured to teach students especially in developing their writing skill. Systemic Functional Linguistic (SFL) which focuses on meaning and function behind language is now seen to be well-implemented. The study tried to analyse student's piece of writing on one type of text in which Hotel Industry students as the sample of the study should master known as recount text. Purposive type of sampling was chosen since there was only one text analysed which was seen as the most problematic one. Content analysis as the implementation of qualitative research was chosen as the design of the study. The findings showed that the major problem student encountered was mostly on grammatical structures in which there were found some errors on it, especially on the use of prepositions and sentence combination. Regarding the three metafunctions, it was known that the students had been able to accomplish all criteria of recount text, such as using mostly material processes which deals with ideational metafunction, using correct tense and subject to fulfil the mood exists in interpersonal metafunction, and using reiteration and zigzag pattern as representation of textual metafunction. However, since there was problem to overcome regarding the ungrammatical structures; a strategy known as "POWER" which stands for Plan, Organise, Write, Edit, and Revise was proposed which is hoped to help students developed a well-constructed text fulfilling all sine qua non attributes that recount text has.
\end{abstract}

Keywords: Systemic Functional Linguistic (SFL), Recount Text, POWER strategy

\section{INTRODUCTION}

There is actually a misconception in teaching English which is mostly applied by Indonesian teachers in which they tend to focus more on the teaching of the forms of language instead of teaching the meaning and function behind the language. Memorization of rules becomes the ends of the teaching and learning process. Indonesian government, then, through a group of curriculum developer, tries to develop curriculum in order to find a way to solve that kind of problem. In 2004, KTSP (Kurikulum Tingkat Satuan Pendidikan) was introduced to teachers. One characteristic of KTSP which is seen as useful is well-known as GenreBased Approach (GBA). The government awareness of the importance of teaching English which should be functional and be able to lead the ability of students in using the language based on the context became the rationale behind the introduction of GBA in 2004 English curriculum (Emilia, 2005) Some genres are then introduced. According to Kemendikbud (2016), there are seven main genres students of high school should master; descriptive, recount, narrative, procedure, explanation, analytical exposition, and news item.

Today's curriculum -2013 Curriculum-, on the other hand, which implements scientific approach in English as Foreign Language (EFL) teaching, insists students to be able to 'communicate' through language. It asks students to develop their skill in writing which is regarded as a difficult skill to be mastered (Emilia, 2005). (Alwasilah, A. C., \& Alwasilah, 2005) further said that communication in written language is difficult for students and even for teachers. Most of students' skills are far from their learning target and teaching writing so far has not been satisfying. The difficulty in writing is faced not only by those at the beginner level, such as primary and junior high school students; even, those at senior high school level feel the same. Recount text, as one genre both senior high school and vocational high school students should master becomes one type of text that will be analysed further since it is still seen as problematic. Some research regarding the implementation of recount text in English as Foreign Language (EFL) teaching has actually been done before. A research done by (Nurohmah, 2013) revealed that students had problems in writing well-constructed recount text. It is known that students did some mistakes especially on the use of grammar such as the use of tense, verbs, and phrases in regard to the linguistic features that recount text has (Nurohmah, 2013). The finding was supported by (Senjawati, 2016) in which, based on her research, grammatical error was one problem students mostly did. Frequent grammatical errors especially on the use of tense and article were found.

As what has been stated above that nowadays teachers still focus on the teaching of traditional grammar and that there are some ways to solve the problems regarding students' errors in writing based on what traditional grammar says. This study, however, will try to highlight another perspective/ approach which is further known as Systemic Functional Linguistics (SFL). In SFL, different from traditional grammar, language is seen (used) as functional for "it is designed to account for how the language is used" (Michael Alexander Kirkwood Halliday \& Matthiessen, 1994) It focuses on how language use is functional to get things done according to the purposes. A sample of student's writing on recount text was taken and was then analysed fulfilling the principles of Systemic 
Functional Linguistics (SFL) following the three metafunctions; ideational, interpersonal, and textual. Further, a pedagogical plan was proposed in order to overcome the problem existed.

This study, then, attempts at addressing these following questions:

1. What are problems that students encounter in writing recount text analysed by employing Systemic Functional Linguistic (SFL) principles?

2. What teaching strategy is best applied to solve the problems found in student's recount text?

Relevant to its purpose, the study analysed only a writing piece of recount text written by a student of vocational high school grade $\mathrm{X}$ majoring Hotel Industry. The writing was analysed through Systemic Functional Linguistic (SFL) perspective and a pedagogical plan was suggested to overcome the problems found.

The study is intended to give significance for several areas. Theoretically, the study aims at analysing vocational high school student's piece of writing text by implementing the principles of Systemic Functional Linguistics (SFL). The study contributes to the literature in this field by providing evidences and suggestions regarding the problems found. Practically, results of the study can be used as a useful guidance for both teachers and practitioners in English Language Teaching (ELT) in order to implement an appropriate strategy to help students create a well-structured recount text fulfilling its social purpose, schematic structure, and language features.

\section{A. Literature Review}

This section elaborates theories underlying the study. It consists of several subsections: text and context, recount text in a brief, and recount text based on three metafunctions.

\section{B. Text and Context}

Broadly speaking, a text is any meaningful stretch of language -oral or written (Derewianka, 1990). Texts are always produced in a context (Knapp, P., \& Watkins, 2005) Texts always relate to a social environment since people produce it as social subject. In SFL, according to Kress in Emelia text is seen as "the socially and contextually complete unit of language" (Emilia, 2005) "which may be written or spoken, preferably from beginning to end"(Eggins, 1994).

Context, on the other hand, originally meant being woven together, where the prefix con carried the sense of being together and over the passage of the centuries, it has come to refer to those elements that accompany a text by Christie and Misson on (Emilia, 2005). Halliday in (Knapp, P., \& Watkins, 2005) proposed a highly articulated relationship between context and text. Context, or what is going on around a language event, is seen as 'virtual' or having the potential to 'actualise' the event in the form of a text.

The context which influences the language use includes the context of culture and context of situation (Derewianka, 1992). A text is a representation of the context of situation since it is created in that context. Context of situation determines the language choices and the way of structuring texts so that people know some text types or genres 'produced' within the shared context of culture (Agustien, 2004). Halliday proposed three aspects to further analyse the concept of context in any situation that have linguistic consequences; field, tenor, and mode (M. A. K. Halliday, 1976). Field refers to "what the language is being used to talk about" (Eggins, 1994). (Derewianka, 1990) further explained that field refers to "what is going on' -the doings and happenings, who or what is involved in them (the participants), and the circumstances in which they are taking place (where and when). Field is the subject-matter of the text. Tenor concerns "the people involved in the communication and the relationship between them" (Thompson, 2007). The tenor of a text will depend on the roles of the participants and their relationships; how well they know each other, their ages, their relative status, how they feel towards each other (Derewianka, 1990). Lastly, mode is "the channel used in communication" (Agustien, 2004), it deals more with how distant the speaker/ writer is from the listener/ reader in both time and space, and the extent to which the language accompanies the action going on or is distanced from the action (Derewianka, 1990). Those three aspects (field, tenor, and mode) are further called as register (Thompson, 2007). It is known then, that language use will vary from context to context depending on the register.

Context of culture, on the other hand, also gives a purpose and meaning to a text and this allows people not only to describe the register of the text, but also to suggest what the overall purpose or function of a text is, that is the genre the text belongs to (Eggins, 1994). In order to help people achieve the purpose of a text, they may look at the schematic structure of that text; when they do this, they are considering the genre of the text. (Derewianka, 1990), further said that the genre of a text is partly determined by the culture in which the text is used, since different cultures achieve their purposes through language in different ways.

It can be said, then, that texts vary according to their genre (purposes) and their register (field, tenor, mode). The overall structuring of the text is determined by the genre while the language patterns found within the text is determined by the register.

\section{Recount Text in a Brief}

"When we tell someone what happened, we can call it a Recount", (Derewianka, 1990) A recount text is a text which tells the reader about something that has happened. Warner according to (Derewianka, 1990), the purpose of recount text (genre) is to tell what happened. (Palmer, 2011) added that recount text is also aimed at retelling several events and is usually from the point of view of someone who was there in certain situation. 


\section{RETORIKA: Jurnal Ilmu Bahasa, Vol. 4, No. 1 April 2018, Page 45}

As many other texts, besides the social function every text has, recount text also has two major aspects; schematic structure and linguistic features. There are three elements of schematic structure that recount text has; (1) orientation, (2) sequence of events, and (3) re-orientation (Gerot, L. \& Wignel, 1995). Orientation provides the setting and introduces the participants. Such an element often has a time reference (for example, last holiday). Events, the second part, tell what happened and in what sequence it exists. In this part, temporal and often addictive connections are important in creating the sequence. Some expression of attitude or emotional response to events is often introduced for this adds interest. The last, re-orientation, is an optional one, it tries to close the events or story. Reorientation is often done by returning the participants to the point when they started.

(Gerot, L. \& Wignel, 1995) further stated some linguistic features found in recount text; (1) specific participants, (2) material processes, circumstances of time and place, (4) past tense, (5) temporal sequence.

\section{Looking at the Three Metafunctions}

First metafunctions to be analysed is the ideational metafunction. Recount text is mostly used material processes since the verbs presented at the texts are mostly in a form of action verbs which convey the physical actions; such as singing, dancing, swimming, reading, etc. The material processes are used in order to show readers/listeners that there are sequences of events surrounding the text. Those kinds of events are represented by the use of action verbs (material processes). However, some other types of processes are also found in recount text. Relational process, known by the use of words such as is, are, am, has, etc., are also found, though the use of those types of words (processes) is not as much as the material process. Mental process is also sometimes used by writer - here is students while expressing their ideas through writing the recount text. Emotive mental process such as feel, like, love, etc. sometimes can be found in students passages. The verbal process one, is maybe the one which is less found in writing recount text, since it is not usual for students to write both direct and indirect sentences in their piece of passage. Other aspect that should be concerned is the use of participant. It can be found that recount text is mostly used specific participants which may present as the actor of the sentence or even the goal. First and third person pronouns are those mostly used in writing recount. The last is the circumstance. Some additional information are usually added in order to create a really meaningful and understandable text. Circumstance in a form of manner such as beautifully, slowly, carelessly, etc., is used to further describe the events or the processes that the participant does. Extent, such as usually, never, always, rarely, etc., is also added to link the time and show the duration of the events.

The second metafunction is the interpersonal metafunction which concerns most on the mood and modality. This may be the most problematic one that students encounter while creating recount text. A matter of finiteness which doesn't exist in students L1 really burdens most Indonesian students. The use of past tense which exists in writing recount is seen as difficult thing to comprehend. The speech functions or speech act used in recount text is mostly in a form of declarative functioning as the way to give information to others. Adjunct, especially conjunctive adjunct and also modal adjuncts are the ones which mostly found in recount text since it consists of linking words to do with time and conjunctions, such as after, before, on the other hand, unfortunately, and etc.

The last is the textual metafunction which deals with how the writer make messages conveyed by the text fit together. This one mostly deals with the cohesion and coherence of the text or passages. In order to successfully reach the coherence and cohesion, first and foremost writer will deal with thematization system which consists of the Theme and Rheme of clause(s). Based on Butt (2003) there are three types of theme; topical theme, interpersonal theme, and textual theme. The textual one is mostly found in recount text, since it is used to connect words and clauses together, for example the use of conjunctions but, and, then, however, etc. The experiential theme, since it conveys the subject or the participant is a must-exist theme in recount text. The interpersonal which mostly used a set of manner adjuncts such as unfortunately, oddly, hardly, luckily, etc., are also found in recount text/ passages.

\section{E. Previous research regarding recount text analysis employing Systemic Functional Linguistics (SFL) principles}

In Indonesian EFL contexts, particularly, since recount text is introduced to both junior high school and senior high school level, it is believed that a well-understanding of a good recount text should be accomplished. Teachers, especially, should be able to teach recount text using appropriate strategy so that the objective which the curriculum stated could be achieved. Some researchers did analyses on students' recount text to see whether students have been able to write a well-constructed recount text or not. Systemic Functional Linguistics (SFL) was also implemented in order to analyse the text thoroughly through analyses on the three metafunctions. First research was done by (Nurohmah, 2013). She investigated students' writing on recount text by identifying its schematic structure and linguistic features. The findings showed that most students were successful in putting the schematic structures of recount text. However, dealing with the linguistic features, most students had problems regarding grammatical structures such as the use of tense, phrases, verbs, and etc. (Yunita, 2016) analysed recount text by specializing the analysis on its thematic progression. It is known that based on her research which focused on recount text written by vocational high school students, reiteration pattern was the one that students used most. It meant that 
students tended to make the text focus by repeating the same element as Themes. The last is (Senjawati, 2016) who tried to analyse students' recount text based on its transitivity. Her research showed that the students' text consisted of material, mental, relational, verbal, and existential processes which had fulfilled the criteria of recount text's linguistic features.

\section{F. Concluding Remarks}

This section has elaborated the theories underlying the study. In a general sense, the study tried to analyse the student's recount text by using Systemic Functional Linguistic (SFL) features which analysed it based on the three metafunctions. The features of recount text which were proposed by (Derewianka, 1990) were used as the basic principle in knowing the criteria of the student's recount text.

\section{METHODS}

This research is aimed at analysing student's recount text by employing Systemic Functional Linguistic (SFL) principles. A sample of text from a student of vocational high school at grade $\mathrm{X}$ majoring Hotel Industry was chosen. Purposive type of sampling was employed since only one text was chosen among the whole students' text at class. The text chosen was the one which was seen as the most problematic one compared to the other texts by analysing mostly on the errors made by the students. It is believed that in-depth analysis could be resulted by focusing only on the chosen text that the result could be used to represent the most problematic error in a single classroom context. A qualitative research by implementing case study was then chosen since it needs further explanation in which general principles are resulted inductively from specific observation (Malik, R. S., \& Hamied, 2014). It is further stated that qualitative study is best chosen to get deep comprehension on an issue (Malik, R. S., \& Hamied, 2014).

The format followed in this study was a content analysis. (Neuman, 2002) stated some objectives of content analysis, such as to analyse information, or content, which may be any document, written, or oral. He further defined it as a technique to analyse the content of certain text.

By employing content analysis, the text written by student was then analysed based on the principles and features of Systemic Functional linguistics (SFL) by dividing it into three metafunctions; interpersonal, ideational, and textual. Besides, other aspects such as social purpose of the text, schematic structure, and linguistic features were also analysed.

\section{FINDING AND DISCUSSION}

This section presents and discusses the findings relevant to the focus of the study. To make it clear, the findings section is divided into two main sections; (1) student's sample text analysis; social purpose, schematic structure, language feature, grammatical errors; and (2) language features from Systemic Functional Linguistic (SFL) perspective; ideational metafunction, interpersonal metafunction, textual metafunction.

\section{A. Student's Sample Text Analysis \\ 1. Social Purpose}

As what has been stated earlier that recount text is meant to tell the reader that something has happened in a sequential order of events. The sample taken from student's piece of recount text writing within the topic of 'my holiday' has fulfilled the social purpose of recount text as general. It successfully tells reader the events or the things that the writer -here is student- did while she had her holiday. It can be concluded that there is no problem found in relation with fulfilling the social purpose of the text.

\section{Schematic Structure}

Looking at the piece of recount text writing made by the student, she also has successfully written it based on the schematic structure suggested in recount text. She started her writing by stating the orientation, telling some basic information such as the participant involved, the time, and the place of the events. She, then, wrote the events she experienced under the topic of 'my holiday' and she has successfully written it in sequential order; starting from the activities she did in the first event (watching performances in Cikapundung street) and then moves to other events; second event (going to Mesjid Agung), third event (having activities at home). She ended the writing by stating the reorientation, expressing the feeling she had during the events.

\section{Linguistic Features (general overview)}

Following the principles of writing recount text by (Gerot, L. \& Wignel, 1995), it can be said that some elements of linguistic features can also be found in the sample analysed. The participant exists in the text is mostly written as the first person ' $\mathrm{I}$ ' since belongs to personal recount which deals with retelling activity that the writer/speaker has been personally involved in (Derewianka, 1990). Material processes, as the second feature, are mostly found in the sample of text. The student used some action verbs such as went, came, watched, took, slept, played, and did. Twelve out of twenty sentences written used material processes to convey the verb. Third feature, circumstances of time and place, are also found. Some words expressing circumstances of time and place written by the student are last holiday, there, at home, everyday, and some vocatives such as Mesjid Agung, Gedung Merdeka, Cikapundung street, and so on. Fourth is the use of past tense. It can be seen that the student has successfully used past tense in most of her sentences from the orientation until the re-orientation. There are no verbs written by using any other types of tense besides the use of past tense. Some examples of past tense written in the text are words like went, came, watched, took, felt, decided, slept, played, etc. Last feature, the use of temporal sequence such as 
then and after that are also found in the text.

It can be concluded, then, that the student successfully fulfils the principles of recount text, dealing with the social purpose, schematic structure, and linguistic feature. The table below may describe it further.

Table 1

schematic structure and linguistic feature analysis

\begin{tabular}{cc}
\hline $\begin{array}{c}\text { Schematic } \\
\text { Structure }\end{array}$ & Text \\
\hline & My Holiday \\
Orientation & $\begin{array}{c}\text { Last holiday, I went to Cikapundung street, at } \\
\text { beside Gedung Merdeka. I went for attended } \\
\text { an event there. I came with my friends Anas, } \\
\text { Ka Dony, and Ka Adit }\end{array}$ \\
& \\
Event 1 & $\begin{array}{c}\text { In there, we watched many performs. Then } \\
\text { we took some pictures with cosplayers. We } \\
\text { also took a picture with someone was wearing } \\
\text { funny costume. That's funniest costume ever } \\
\text { seen. }\end{array}$ \\
& \\
\hline
\end{tabular}

After that, we felt so tired we decided to went to Mesjid Agung. In there we slept a sec for

Event 2 rest. Then we played some little games. We were exhausted and time to go home.
This part gives the information of what, who, when, and where.

-Pink Highlight: Specific participant

- Yellow Highlight: Circumstance of time

-Torquise Highlight: Circumstance of Place

-Green Highlight: Past tense

-Red Highlight: Additive Conjunction

This sequence of events part gives the information abot the series of the story, this answers the question how.

-Pink Highlight: Specific participant

- Yellow Highlight: Circumstance of time

-Torquise Highlight: Circumstance of Place

-Green Highlight: Past tense

-Red Highlight: Additive Conjunction

-Grey Highlight: Temporal Conjunction

At home, I could not play with my friend.
Because I have no friend and I just stayed
home. Usually i just watched some anime
videos. I also heard some songs when i was
being bored. I did that everyday during
holiday.

Re-Orientation

My holiday was flat. Because I could not go out with my friend for everyday. I felt so lonely during holiday at home.
-Pink Highlight: Specific participant

- Yellow Highlight: Circumstance of time

-Torquise Highlight: Circumstance of Place

-Green Highlight: Past tense

\section{Grammatical Error}

From the table above, it can be seen that there are some sentences or words written in a red colour. Those red colour sentences or words are written by using incorrect grammar. Although the student as the sample of the study has successfully fulfilled the social purpose, schematic structure, and linguistic features of recount text; she did some mistakes in using (1) preposition ( $\ldots$ at beside Gedung Merdeka) the preposition at should be omitted, (2) noun (we watched many performs) the word performs should be performances, (3) Adjective clause (... someone was wearing funny costume) it should be written as someone wearing funny costume/ someone who was wearing funny costume, (4) Comparison (that's funniest costume) it should be written as that's the funniest costume, (5) Pronoun (that's funniest costume ever seen) the pronoun I should be there: that's the funniest costume I've ever seen, (6) Infinitive (we decided to went to Mesjid Agung) to should be followed by infinitive: we decided to go to Mesjid Agung, (7) Adverb of time; the use of usually, everyday, convey present tense instead of past tense, and (8) passive (when I was being bored) it should not be written in passive: when I was bored.

Besides those grammatical errors, there are also found some incorrect use of conjunctions, punctuation, and a matter of capital letter. Using because at the first sentence is incorrect, omitting the coma after temporal conjunction is also incorrect, writing the participant 'I' also should be in capital letter to make it correct.

\section{B. Language Features from Systemic Functional Linguistics Perspective \\ 1. Ideational Metafunction}

This type of metafunction deals with what so called as Transitivity System. Teich defined 
transitivity system as the predicate types of a language and the participant roles with which they combine. Regarding this system, there are three main functional roles; participant, process, and circumstance which are realized as follows: processes by verbal groups, participants by nominal groups, and circumstances by adverbial groups or prepositional phrases (Michael Alexander Kirkwood Halliday \& Matthiessen, 1994) In terms of processes, there are six types of process exist; material, mental, verbal, relational, existential, and behavioural (Michael Alexander Kirkwood Halliday \& Matthiessen, 1994).

As what has been stated above, most of the processes applied in the text is in the type of material processes (twelve out of twenty clauses). This type dominates most of the sample text the student wrote. It means that the student's text has fulfilled the criteria of recount text in which material process is one linguistic feature of recount text. Further, (Emilia, 2005) stated that in retelling experience(s), using action processes are important. The material processes can be found in the clauses: I went to ... (clause 1), I came with... (clause 3), We watched... (clause 4), we took... (clause 5), and so on. Besides material processes which dominate most, it is also found that the student use relational processes. There are five clauses among twenty clauses found using this type of process. The clauses are all used to assigned a quality (attributive processes) in which three of the clauses use intensive relational process and the rest uses possessive relational process. The clause "my holiday was flat" for example, uses intensive relational process in order to give the conclusion (re-orientation); while the clause "I have no friend" uses possessive relational process. Mental process is also found in the text. Only one clause uses this type of process. It is used mostly to show the writer's feeling, emotion, and expression. It can be seen in this clause "we were exhausted". That clause belongs to the affective or reactive type of feeling. The participant roles in that process, then, are senser and phenomenon. Last process found in the text is behavioural process in which it conveys processes of physiological and psychological behaviour. In the text, there are two clauses having this type of process. Those clauses are "we decided to..." and "I also heard some songs...". The words decide and hear are examples of behavioural process where the participant acts as behaver.

It can be concluded that there are four types of processes among six types of processes found in the text. The student prefers to use material, relational, mental, and behavioural processes instead of verbal and existential processes. However, her text can be regarded as good recount text since it fulfils the feature of recount text especially in ideational metafunction by the use of material processes.

\section{Interpersonal Metafunction}

Talking about interpersonal metafunction, one thing to be analysed is the mood system. The mood element consists of two parts; subject and finite. It is a matter of finiteness which mostly becomes the main problem Indonesian students, especially, have. Since finite element conveys the tense, modality, and polarity; it is sometimes seen as the most crucial aspect in every types of text. Looking at the tense used in the text, the student has successfully used past tense as representation of recount text in all of her clauses/ sentences since it tells past events.

Declarative type of mood is also used in all sentences created. It is relevant with the purpose of recount text which is created in order to give information to the readers. Both positive and negative polarities are applied in the text. The negative ones, especially, are used in the form of modality. One example is "I could not play with my friend". There are only two clauses consisting modal finite. All of them use the modal (can) in order to express ability and are intended to show the writer's opinion.

Some adjuncts are also found in the analysis of mood. Most of the clauses use circumstancial adjunct telling the place and the time that the participant does. An example is "I went to Cikapundung street" the words Cikapundung street is considered as circumstancial adjunct. Other use of adjunct is mood adjunct especially in expressing intensity and usuality. The last is conjunctive adjunct such as the words then and after that. However, since this type of adjunct have a textual function, it falls outside of the analysis of mood.

\section{Textual Metafunction}

It is believed that focusing the students' writing on the Thematic progression will be very useful in helping students to communicate their ideas successfully. Looking at the text produced by the student, in terms of types of theme, only two types of theme are used in the text; topical theme and textual theme. There is no interpersonal theme used in the text. Topical theme is the one which appears most in the text which is then followed by the textual one. According to Butt dominating occurrence of topical theme in students' texts signals the students' ability to deliver what the text is about. It also indicates the students' ability to demonstrate where the information has come and where it is going. added that topical theme gives thematic status to an element structure of the clause. The reason on why the student chooses not to use interpersonal theme is that she tends to be concerned with facts and have single modality of certainty' (Emilia, 2005). Being able to use textual theme, on the other hand, shows successfulness of student ability to shape and structure the text. Forey said that textual theme is an important means for expressing logical links between the ideational content if the messages in a text and thereby helping understand the text". Some conjunctives represent the textual theme found in the text are then, because, and after that. 
Table 2

thematic progression

\title{
Orientation
}

Last holiday, I went to Cikapundung street, at beside Gedung Merdeka.

I went for attended an event there.

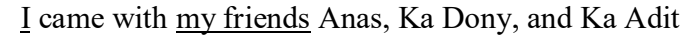

\author{
Record of Events \\ In there, we watched many performs. \\ Then we took some pictures with cosplayers \\ We also took a picture with someone was wearing funny costume. \\ That's funniest costume ever seen. \\ After that, we felt so tired we decided to went to Mesjid Agung \\ In there we slept a sec for rest. \\ Then we played some little game \\ We were exhausted and time to go home. \\ At home, I could not play with my friend \\ Because $\underline{I}$ have no friend and $\underline{I}$ just stayed home \\ Usually i just watched some anime videos \\ I also heard some songs when i was being bore \\ I did that everyday during holiday.

\section{Re-Orientation} \\ My holiday was flat \\ Because I could not go out with my friend for everyday \\ $\underline{I}$ felt so lonely during holiday at home.
}

From the table above, it can be seen that mostly, the student's thematic progression pattern is reiteration pattern which indicates that the student provides the text with clear focus in order to help maintaining a strong topical theme (Eggins, 1994). It also indicates that the student tends to make the text focus by repeating the same element as themes. The theme reiteration helps maintaining a strong topical focus.

Another pattern found is zig-zag pattern. It has the second place of the mostly occurring thematic progression pattern in the sample text. The use of zig -zag patterns indicates that the student creates or introduces newly information by promoting the Rheme in a clause to the Theme in the subsequent clause. Such example is found in clause 8 and 9 ; in which the Rheme in clause 8 becomes the Theme in clause 9 .

\section{Discussion}

In order to help students create a wellconstructed text, an appropriate strategy based on the case found in a given classroom needs to be implemented. In accordance with the problems found in the text being analysed in the study, it is suggested that teachers employ a strategy which is proven as appropriate in teaching writing which further known as "POWER". The word POWER actually stands for Plan, Organise, Write, Edit, and Revise. It is introduced (Englert, C.S., Raphael, T.E., Anderson, L.M., Anthony, H.M., Fear, K.L., \& Gregg, 1988) as a strategy in teaching writing skill which can be implemented for teaching students in all levels.

A pedagogical plan set to overcome the problem encountered by students in writing recount text is presented below.

\section{Writing with POWER; Plan, Organise, Write, Edit, Revise}

It is known that nowadays the curriculum implemented in Indonesia (2013 Curriculum) follows the steps proposed in scientific approach which consists of observing, questioning, experimenting, associating, communicating. However, there are many strategies teachers can develop following the steps presented. One strategy, especially in teaching writing which has been proven as appropriate to implement as what has been explained above is known as "POWER" which stands for Plan, Organise, Write, Edit, and Revise.

(Englert, C.S., Raphael, T.E., Anderson, L.M., Anthony, H.M., Fear, K.L., \& Gregg, 1988) in their work, proved the benefits of implementing the strategy. They tried to analyse the problem made by $4^{\text {th }}$ and $5^{\text {th }}$ grade students in their writing. It is found that there were 3 categories of problems; (1) general writing ability and fluency, (2) informant status in the communicative act of writing, and (3) knowledge and control of the thinking and organizational strategies associated with writing. An instructional program that involves cognitive writing strategies, which further was known by POWER writing strategy was then proposed to overcome the problems. Moreover, (Englert, C. S., Raphael, T. E., Anderson Helene M. Anthony, L. M., \& Stevens, 


\section{RETORIKA: Jurnal Ilmu Bahasa , Vol. 4, No. 1 April 2018, Page 50}

1991) did another work regarding the writing of expository text. An intervention was given to students in order to help increase students' expository writing abilities. The intervention was mostly fulfilling the principle of POWER writing strategy which further was resulted to such effective findings to (1) promote students' expository writing abilities during the intervention, and (2) lead to improve abilities on a near transfer activity. The results support the importance of instruction that makes the writing processes and strategies visible to students. In accordance with the problem regarding the sample of text in the study, "POWER" can be implemented to overcome it. Since "POWER" strategy is a recursive process which means that the procedure/ step can be applied repeatedly, teacher may implement the strategy before the students try to write the first draft and after the draft has been analysed. Take an example, at the very first time teacher introduce recount text and ask students to write the text, he/she implements the "POWER" strategy. After all the steps done; Plan, Organise, Writing, Edit, and Revise; and that there are found some problems in students' text, teacher may go back to the "P" step (Plan) and ask students to rewrite the text. What makes this strategy 'special' is that it can be implemented in whatever approach the teachers follows. Another specialty is that "POWER" is easy to differentiate or adapt and that it tailors to the students' needs. Any piece of writing/ text types can be taught by using the strategy.

First step is PLAN. In this step, teacher brainstorms students' knowledge regarding recount text by proposing some questions or showing them pictures, realias, or a piece of text in which they encounter some problems in it. This one looks like the step of 'observing' and 'questioning' in scientific approach in which teacher together with the students gather information from many sources available, such as internet and library. In this step, students may write the resources they get to further help them answer the questions proposed. Such questions that can be addressed in this step, for example are 'what is my topic?', 'who is my audience?', 'what do I already know about my topic?', 'why am I writing the text?', and etc. By answering those questions, one problem regarding writing a text, here is recount text, may be overcome. The problem especially is the one dealing with social purpose of the text. By being able to answer the questions proposed and collect as many sources as they can, students should be able to reach the social purpose of the text correctly.

Second step is ORGANISE. This step of writing process requires determining how to arrange ideas. It is such an essential step since it could help students highlight the main ideas, pace of writing and engage the reader of the text. By successfully organizing the text, the problem in schematic structure of the text could be easily overcome. Teacher, in this step, could help students by providing organizing think sheet in which students are able to complete a pattern guide in helping them organise their text. A mind-map or tree-diagram can also be used to help students. By showing students the schematic structure of the text discretely, it is hoped that there will be no part/ structure left; that students could fulfil all structures in (recount) text. Such questions regarding this steps to answer by students are, 'what ideas go together?', 'what are my categories?', and 'how can I order my ideas?'.

Next step is WRITE. This is the heart of the whole steps. In this step students are asked to write their own text based on what they have done in the pre-writing steps (Plan and Organise). Since, they have been able to overcome the social purpose and schematic structure, in this step students are faced with other problems such as grammatical errors and the existence of the three metafunctions in the text they write. In helping students to write a new piece of well-constructed writing, teachers may proposed some questions especially those questions known as $5 \mathrm{~W}+1 \mathrm{H}$ (What, Who, When, Where, Why, How). By being able to answer the questions, students could overcome the interpersonal metafunctions problems exist in their writing, since those $5 \mathrm{~W}+1 \mathrm{H}$ questions mostly deal with what interpersonal metafunction covers.

Fourth step EDIT is meant to build students critical thinking and ability in criticizing the text they made. the students are asked to identify in which areas they need clarification or assistance. Editing can be done by both self-evaluation and peer -editing. Self-evaluation means that students should be able to re-read and evaluate their writing by themselves. On the other hand, peer editing needs students' cooperation with others (peers) to edit and even summarize the text. Suggestion from their peers is hoped to help them revise the text and produce a more correct piece of writing. In this step, teacher may provide students with rubric consisting of some criteria in writing a good text. Conventions such as grammar and mecahnics including spelling, punctuation, capitalization, paragraph development, and sentence fluency may be examined through this step. Problems regarding interpersonal metafunction and textual metafunction as well as such grammatical errors are hoped to overcome by fulfilling this step.

Last step, REVISE means that students should revisiting or re-seeing the writing. People usually find difficulties in differentiating the word revise and edit. Revision is not the same as editing where students mainly check for errors with grammar and mechanics. Revising involves adding, deleting, and changing content in order to develop ideas. Dealing with textual metafunction, this is the step in which the students should be aware with what so called as coherence and cohesion in a text. Before producing the final piece of writing, teacher could help students by having a small conference to check, give feedback, and make sure that the problems students had in their previous writing have been successfully overcome or not.

Having been able to fulfil all steps in the strategy proposed, it is hoped that all problems dealing with the three metafunctions; interpersonal metafunction, ideational metafunction, textual 
metafunction; and grammatical errors as well as the social purpose and schematic structure in students' writing, especially recount text writing, could be overcome. Another benefit that the strategy has is that it helps students manage their time in writing and that the possibilities to stop writing in the middle of the process can be reduced.

\section{CONCLUSION}

It is then known that the ability to consider the meaning and function behind the use of language in order to create meaningful texts is seen as important and is hoped to be one way to help learners understand what actually meant by writing such texts so that the goal of the teaching and learning may be pursued. Using Systemic Functional Linguistic (SFL) dealing with the three metafunctions may help to see the connection between the grammar exists in such texts and communication, since the main purpose of both writing and speaking texts is to communicate the texts to others.

Doing analysis on student sample of recount text gives brief understanding on whether the student has successfully fulfilled the three aspects; social purpose, schematic structure, linguistic features; of the text or not. Besides some grammatical errors found in student writing, it can be concluded that the student has achieved the goal of recount text in that she has been able to show the social purpose of the text which is to retell past events. The schematic structure, even, has also been successfully followed. She has been able in putting clauses into the orientation, events, and re-orientation. Linguistic features, as the most complicated one, has also been successfully fulfilled. In the ideational perspective, the use of participants, the existence of processes in which the one which mostly used is material processes, and also the correct use of circumstances has been well arranged. Looking at the interpersonal perspective, the student has successfully applied past tense as one characteristic of recount text which is represented in the finite element. The last, from the textual perspective, the student only follows the reiteration pattern and zig-zag pattern of thematic progression. In short, the sample text can be said as well-written based on the social purpose, schematic structure, and linguistic features. However, it has lots of grammatical errors to be considered further.

In order to overcome the problems found, especially for students of vocational high school in Indonesia which deal with writing piece of recount text, there is a strategy called "POWER" which is proposed. By fulfilling all steps; Plan, Organise, Write, Edit, and Revise; students could be able to criticize their own writing and overcome the problems regarding the three metafunctions; interpersonal metafunction, ideational metafunction, textual metafunction; and grammatical errors as well as the social purpose and schematic structure of the text.

\section{ACKNOWLEDGEMENT}

This research was fully funded by the Indonesia Endowment Fund for Education.

\section{REFERENCES}

Agustien, H. I. R. (2004). Setting Up New Standards: A Preview of Indonesia's New Competence-Based Curriculum. TEFLIN Journal: A Publication on the Teaching and Learning of English, 15(1), 1-13. Retrieved from http://www.journal.teflin.org/index.php/ teflin/article/view/78

Alwasilah, A. C., \& Alwasilah, S. S. (2005). Pokoknya Menulis. Bandung. Bandung: PT Kiblat Utama Buku.

Derewianka, B. (1990). Exploring how texts work. Heinemann Educational Books.

Derewianka, B. (1992). A functional model of language. North Sydney. Board of Studies.

Eggins, S. (1994). Linguistics, An introduction to systemic functional. In London. Pinter Publishers.

Emilia, E. (2005). A critical genre based approach to teaching academic writing in a tertiary EFL context in Indonesia. The University of Melbourne.

Englert, C. S., Raphael, T. E., Anderson Helene M. Anthony, L. M., \& Stevens, D. D. (1991). No TitleMaking strategies and self-talk visible: Writing instruction in regular and special education classrooms. American Educational Research Journal, 28(2), 337-372.

Englert, C.S., Raphael, T.E., Anderson, L.M., Anthony, H.M., Fear, K.L., \& Gregg, S. (1988). A case for writing intervention: Strategies for writing informational text. Learning Disabilities Focus, 3(2), 98-113.

Gerot, L. \& Wignel, P. (1995). Making sense of functional grammar. In Sydney. Antipodean Educational Enterprises.

Halliday, M. A. K. (1976). System and function in language (Edited by Kress, G. London. Oxford University Press.

Halliday, M. A. K., \& Matthiessen, C. M. I. . (1994). An Introduction to Functional Grammar. An introduction to functional grammar. https:// doi.org/10.4324/9780203431269

Knapp, P., \& Watkins, M. (2005). Genre, text, grammar: Technologies for teaching and assessing writing. UNSW Press.

Malik, R. S., \& Hamied, F. A. (2014). Research methods: A guide for first time researchers.

Neuman, L. W. (2002). Social research methods: Qualitative and quantitative approaches.

Nurohmah, I. (2013). An analysis of students' recount text by using systemic functional grammar. Electronic Journal of Indonesia University of Education: Passage, 1(2), 8998.

Palmer, S. (2011). How to teach writing accross the curriculum (2nd Ed.). In London. Routledge 
RETORIKA: Jurnal Ilmu Bahasa, Vol. 4, No. 1 April 2018, Page 52

Taylor \& Francis Group.

Senjawati, D. (2016). Transitivity Analysis of Tenth

Grade Students '. Journal of English and Education, 4(1), 1-22.

Thompson, G. (2007). Introducing functional grammar. Language (Vol. 83). Edward
Arnold. lan.2007.0073

https://doi.org/10.1353/

Yunita, S. (2016). THEMATIC PROGRESSION IN STUDENTS' RECOUNT TEXTS Educational Sciences: Jurnal Ilmi Pendidikan Bahasa Inggris, 1(3), 50-59. 